\title{
Hudson Bay Climate Change and Local Winter Wind Circulation
}

\author{
Farahnaz Fazel-Rastgar ${ }^{(1)}$ \\ York University, Toronto, Canada \\ Email: farahnaz@yorku.ca
}

How to cite this paper: Fazel-Rastgar, F. (2019) Hudson Bay Climate Change and Local Winter Wind Circulation. American Journal of Climate Change, 8, 544-560. https://doi.org/10.4236/ajcc.2019.84029

Received: September 13, 2019

Accepted: December 1, 2019

Published: December 4, 2019

Copyright $\odot 2019$ by author(s) and Scientific Research Publishing Inc. This work is licensed under the Creative Commons Attribution International License (CC BY 4.0).

http://creativecommons.org/licenses/by/4.0/

\begin{abstract}
The meteorological mechanisms causing the recent increase in winter wind speed on Hudson Bay are investigated by examining the NARR dataset (The North American Regional Reanalysis Model) for the past several decades. Winter seasonal changes for atmospheric variables are examined and their interconnections are studied. Yearly mean near-surface temperatures are analyzed from 1948 to denote a rapid warming over Hudson Bay from late 1998 onwards. The surface albedo, air temperatures, mean sea level pressure and wind vector anomalies from 1998 to 2015 have also been studied. The comparison of the $1000 \mathrm{hPa}$ wind vector mean and departures from 1981-2010 (normal period) averages have shown an intensification of anti-cyclonic anomaly pattern over most parts of Hudson Bay. The structure of the wind vector anomalies has revealed a contrast between cyclonic and anti-cyclonic local wind circulations mostly in the east, north and north-west regions along with wind speed increasing at $10 \mathrm{~m}$, increases in near-surface air temperature and decreasing of the surface albedo. The anomalies of the wind vector analysing at different pressure levels show the change in wind direction mostly from northwesterly (zonal wind weakening) to south and easterlies. The polar jet wind vectors at $200 \mathrm{mb}$ during anomaly time (1998-2015) have revealed the changes in magnitude and position. During winter anomaly time, the polar jet at $200 \mathrm{mb}$ has been shifted mostly from rather mean colder north westerly currents to the rather warmer south and easterly anomaly currents over Hudson Bay areas. The yearly historical total accumulated Hudson Bay ice coverage during 1980-2015, using Canadian Ice Service data has shown a slight reduction in the north, north-west and eastern Hudson Bay. The linear regressions of the winter temperature anomaly at $2 \mathrm{~m}$ against albedo anomaly, alongside the wind speed anomaly at $10 \mathrm{~m}$ against air temperature at $2 \mathrm{~m}$, have shown a relationship between these variables. Also, there is a statistically meaningful relation between decreased albedo and increased evaporation.
\end{abstract}




\section{Keywords}

Climate Change, Winds, Hudson Bay

\section{Introduction}

Since 1970, the global average temperatures have increased by $0.2^{\circ} \mathrm{C}$ decade ${ }^{-1}$, because of the emissions of greenhouse gases [1]. Also, recent studies show that the climate change in the Arctic regions, has been at least twice as fast as the global average [2]. The decline in Arctic sea ice is the most dramatic indicator of the Arctic warming. Dynamical and physical changes such as thermal and radiative forcing in both Arctic atmosphere and ocean impact on the sea ice and the atmospheric changes act as a driver for the sea ice changes [3]. Feedbacks due to the reduction of ice concentration, surface albedo and ice thickness are primarily responsible for the amplification of the temperature signal [4] [5] [6]. The rate at which changes are occurring in the Arctic makes it a place that is quickly changing and where the environment and its people are likely to be strongly impacted.

Wind plays a key role in the Arctic and sub-Arctic atmosphere and the water cycle. For instance, the wind changes in seashore areas are very important because of their impact on hydrodynamical aspects [7] [8] [9]. Any changes in weather patterns due to wind shifts in the Arctic would be important, both in regional and global climatic changes. Understanding the coastal wind changes is one of the key factors to expect the future environmental changes linked to greenhouse gas changes [10]. The recent studies related to the atmospheric circulation anomalies and trends during winter have shown that summer sea ice decreases over the east part of Europe and north of Alaska are associated with the recent strong anti-cyclonic circulation [11]. Also, the study of the composite mean surface wind stress and sea ice anomaly vectors during summer revealed that the yearly September sea-ice area decreasing is due to the anti-cyclonic circulation over the Arctic during the ice-loss years whereas the cyclonic circulation is linked to ice-gain years [12].

This study can provide a better understanding and denote an assessment for recent local wind trends in Hudson Bay, located in the Canadian Arctic and Sub-Arctic regions (Figure 1). Wind circulation is one of the major atmospheric elements which has important potential impacts on local weather and climate change in Hudson Bay which as an example may cause the increase of the frequency of blizzards. However, the effects of climate change on Hudson Bay winds are not well understood and need more research. The seasonal ice reduction in Hudson Bay affects the surface albedo and near-surface meteorological and physical structures such as air temperature, humidity and cloudiness.

\section{Hudson Bay Climate}

Hudson Bay (Figure 1) is the largest inland sea in the world extending between 


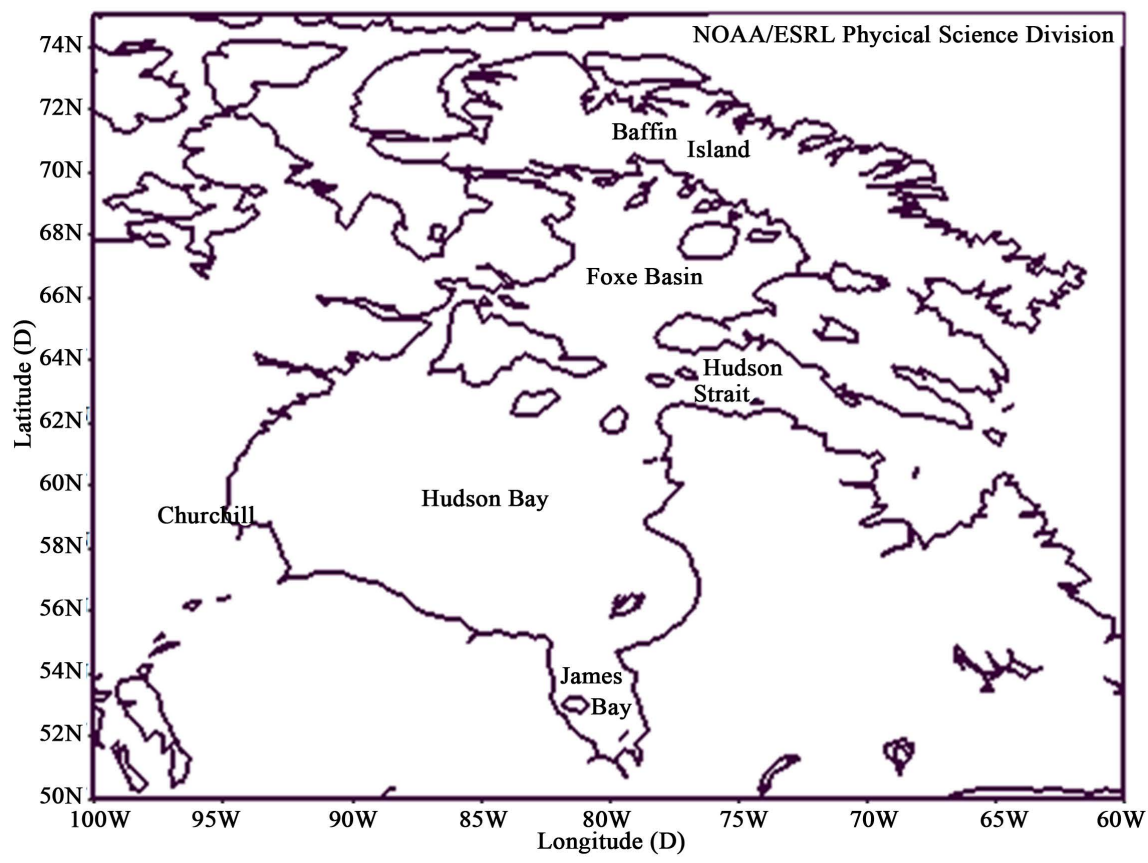

Figure 1. The geographical location of Hudson Bay. Source from http://www.esrl.noaa.gov/psd/.

51 and 63 degrees north latitude and has an area of total 637,000 square kilometres. It is bounded by Nunavut territory on the north and west, Manitoba and Ontario on the south and Quebec on the east. Hudson Bay is connected with the Atlantic Ocean via Hudson Strait from the northeast and via Foxe Chanel to the north with the Arctic Ocean. It is located in the Canadian Arctic and Sub-Arctic regions. Its climate depends largely on the water surface, and it is anomalously cold in comparison with the other regions with the same latitudes, linked to the influence of the seasonal variation of its ice cover even during some parts of summer [13] [14] [15]. The freezing occurs in late October and November and in January and February the Bay is completely covered with the ice pack [16] [17]. Ice melting begins in May and the ice rapidly decreases by June, when cloudiness and fog increase. From mid-August to late October, it is free of ice [16] [18] [19]. The southwest part of Hudson Bay is the region having ice cover extending into the summer due to ice advection by winds and counter-clockwise gyre ocean currents [20] [21].

\section{Methodology}

This study investigates climate change and the increase in wind speeds over Hudson Bay and its relation to sea ice decline. This study uses NARR (The North American Regional Reanalysis Model) data over the Hudson Bay region. The NARR model [22] uses a very high-resolution NCEP Eta Model (the grid resolution is approximately $0.3 \times 0.3$ degrees or $32 \mathrm{~km}$ at the lowest latitude) together with the Regional Data Assimilation System (RDAS) which significantly, assimilates the precipitation along with other variables. The improvements in 
the model and assimilation have resulted in a dataset with substantial improvements in the accuracy of temperature, winds and precipitation compared to the NCEP-DOE Global Reanalysis 2. The outputs include 8 times daily data at 29 vertical levels. The NCEP monthly Dataset [23] is available from 1948 and NARR data is available from 1979 for 8-times daily, for every 3 Universal Time Coordinate.

We investigate the available historical archived model dataset by analysing mean values to understand the general structure and anomaly patterns and then study shifts and departures from climatological mean values from 1981 to 2010 (normal period) as a base, following World Meteorological Organization (WMO) Policy, which suggests using the latest decade for the thirty year average. Studying the anomalies can describe the climate variability and make it possible to understand the changes and anomaly structures on the regional scale when the high-resolution NARR data is used. Besides, the anomalies give a reference frame which allows more meaningful comparisons between locations and more accurate calculations of trends. Also, this study uses the statistical analysis such as t-tests for temperature at $2 \mathrm{~m}$, wind speed at $10 \mathrm{~m}$ and surface albedo for mean values during winter anomaly period (1998-2015) with the values during climatology normal periodic time to examine for an existence of a significant difference between anomaly period and climatology normal periodic time for mentioned parameters over Hudson Bay. For this stage, at first the multipledimension NetCDF data set for the study period (December-February 1998 to 2015) from NCEP/NARR website (https://www.esrl.noaa.gov/psd/) have been downloaded. Then, the obtain Hudson Bay shapefile for the coastal boundary ArcGIS from Canadian census website (http://www12.statcan.gc.ca/census-recensement/2011/geo/bound-limit/bound-1 imit-2011-eng.cfm) have been extracted. In the next step the extract information for latitude and longitude Hudson Bay shapefile also extracted and then the information from both NetCDF data set and Hudson Bay shapefile for the coastal boundary ArcGIS from Canadian census website have been combined. In the last step the data have been exported to the excel files for farther analysis for different variables.

\section{The Recent Warm Trend in the Hudson Bay Area}

The time series of yearly average $1000 \mathrm{mb}$ and $850 \mathrm{mb}$ air temperatures from 1948 to 2015 shows the rapid increase from late 1998 in the Hudson Bay area (Latitude: $50^{\circ} \mathrm{N}-65^{\circ} \mathrm{N}$ and Longitude: $265^{\circ} \mathrm{E}-285^{\circ} \mathrm{E}$ ) and a significant increase in average yearly datasets for $1000 \mathrm{mb}$ and $850 \mathrm{mb}$ air temperatures in the Hudson Bay region during 2010 (Figure 2(a) and Figure 2(b)). Figure 2(c) shows a time series of yearly mean sea surface temperature over the area of study for the same time as Figure 2(a) and Figure 2(b). This Figure displays a dramatic change from 1998 over the study area. This maximum change corresponds to the lowest value in the North Atlantic Oscillation index (NAO) which is shown in Figure 2(d). 


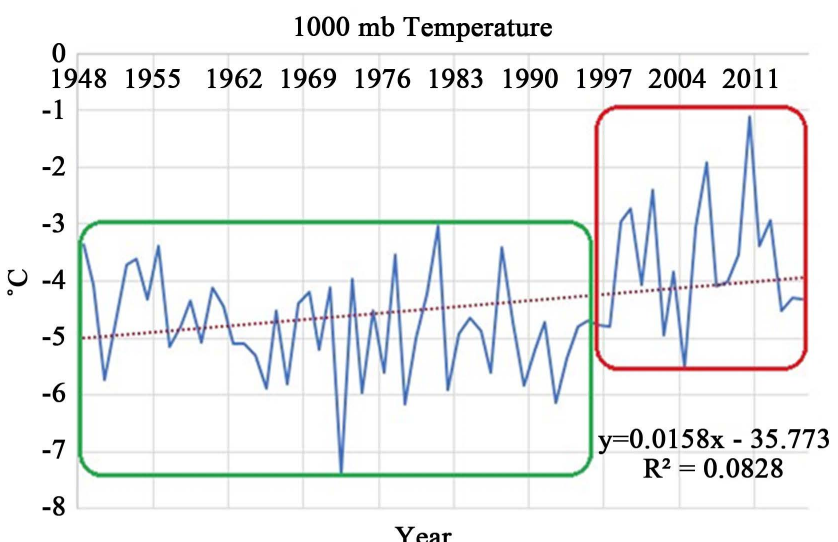

(a)

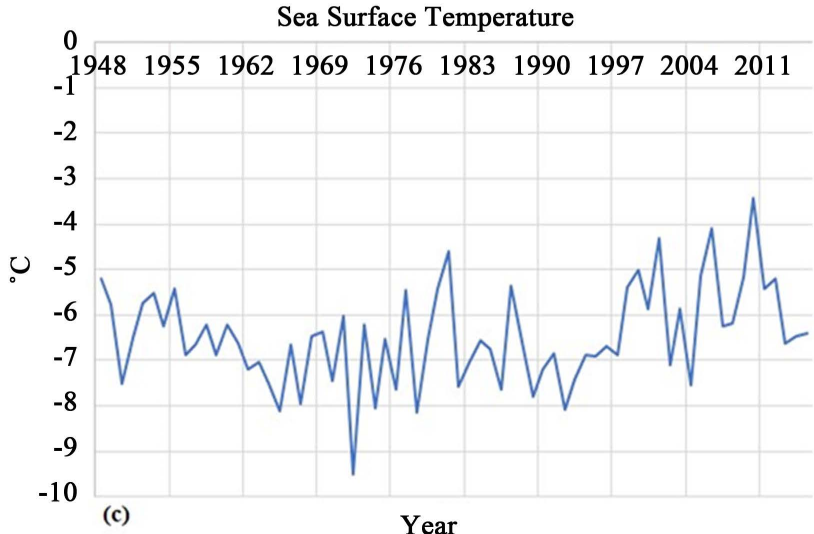

(c)

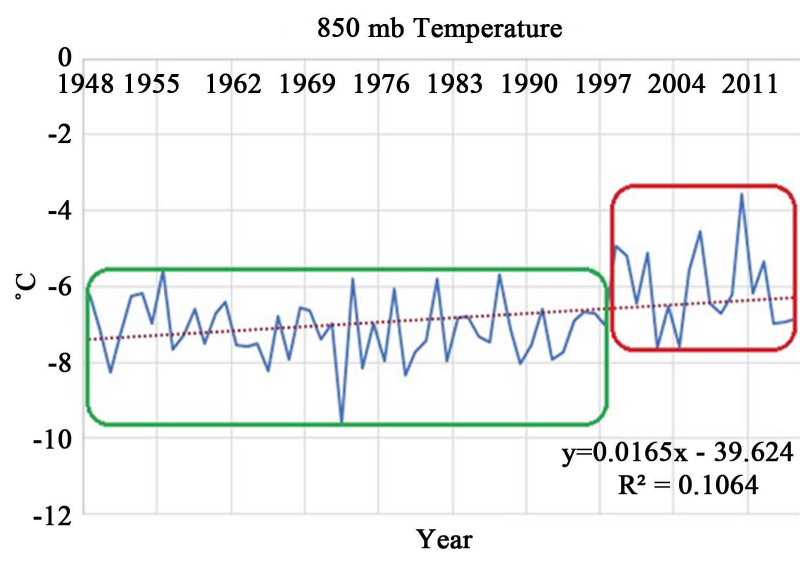

(b)

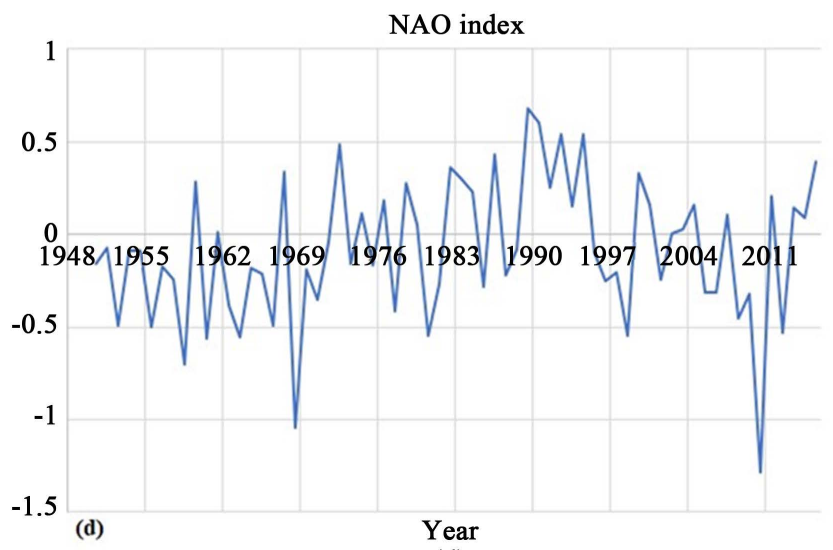

(d)

Figure 2. Yearly mean $1000 \mathrm{mb}$ air temperatures (a); $850 \mathrm{mb}$ air temperatures (b); sea surface temperatures (c); yearly average NAO index from 1948 to 2015 (d).

Additionally, the results of some models such as NCEP/NCAR R1, NCEP CSFR, NCEP/DOE R2, ERA-Interim, NOAA ERSST, COBE, CRUTEM4, JRA-55 are presented in Figure 3. All models show the increase in $2 \mathrm{~m}$ air temperature from late 1998 in the Hudson Bay region. Also, the long-term daily maximum and minimum Hovmöller diagrams (from 1948-2015) show this rapid change from late 1998 (figures have been not presented here).

\section{Yearly Historical Ice Coverage in Different Part of Hudson Bay}

The yearly historical total accumulated Hudson Bay ice coverage during 1980-2015, using Canadian Ice Service data

(http://iceweb1.cis.ec.gc.ca/IceGraph/page1.xhtml) for the weeks of 0101-1225 for all seasons from 1980 to 2015 for north (a), north-west (b), east (c) and central (d) parts of Hudson Bay are examined. This results show the negative yearly trends for all parts of Hudson Bay changing from largest to lowest values in the north $\sim-3.25(+/-1.86) \%$ per decade, north-west $\sim-2.36(+/-1.2) \%$ per decade, east $\sim-1.99(+/-1.56) \%$ per decade and central part $\sim-1.57(+/-1.24) \%$ per decade respectively from 1980 to 2015 (Figures are not presented here). 


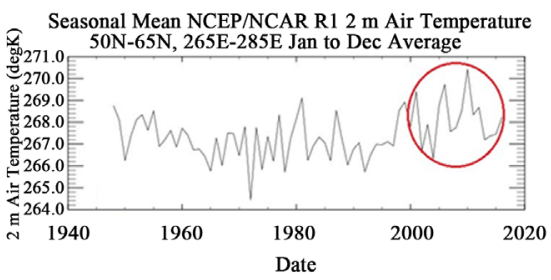

(a)

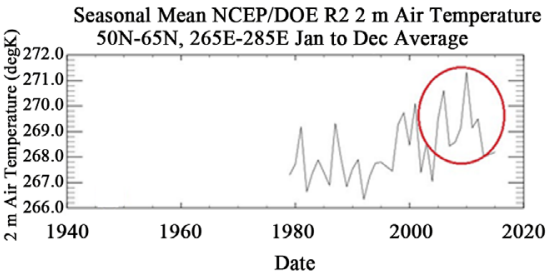

(c)

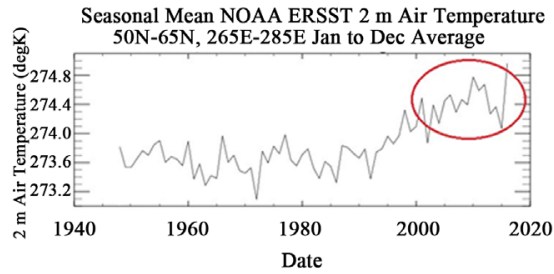

(e)

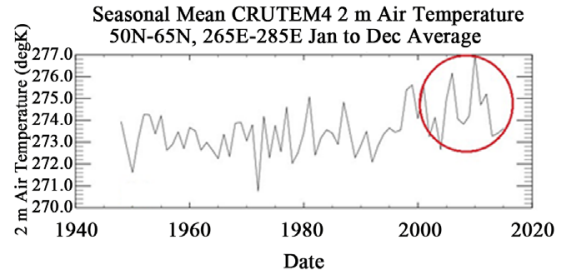

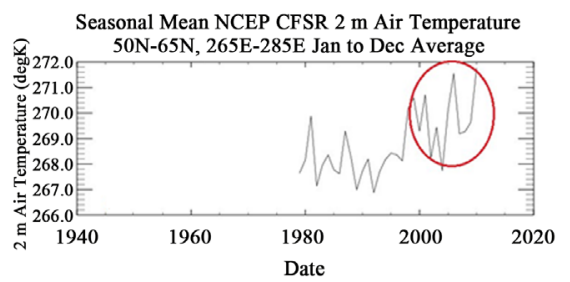

(b)

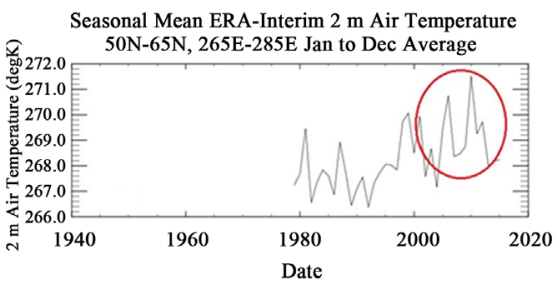

(d)

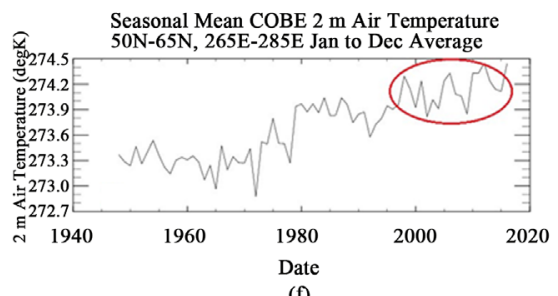

(f)

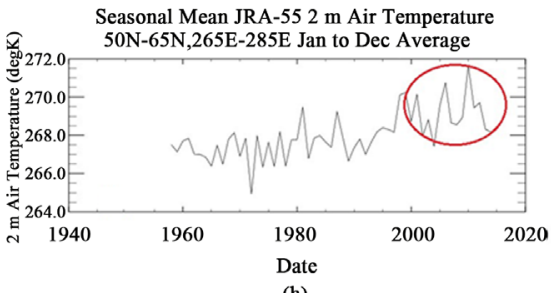

Figure 3. Different models show an increase of $2 \mathrm{~m}$ air temperature in Hudson Bay from late 1998.

\section{Winter NCEP/NARR Physical and Meteorological Data Analysis in Hudson Bay Area}

This section presents results for winter time (DJF) using NCEP/NARR reanalysis data for meteorological parameters such as $1000 \mathrm{mb}$ wind vector, $10 \mathrm{~m}$ wind speed, mean sea level pressure, zonal and meridional winds at $850 \mathrm{hPa}$, vertical profiles of mean and anomalies of zonal wind, polar jet stream and vertical velocity (omega) at $700 \mathrm{hPa}$ mean and anomalies for the Hudson Bay region from December-February 1998 to 2015 (study period). Here, anomalies for departures from 1981-2010 (normal period) are analysed.

\subsection{Wind Vector Pattern at $1000 \mathrm{mb}$}

Figure 4(a) shows mean DJF wind vector at $1000 \mathrm{mb}$ during study period and Figure 4(b) shows the wind vector anomaly map of departures from the normal period. Areas with cyclonic and anti-cyclonic circulations are shown with $\mathrm{C}$ and A. The mean near surface wind circulation over Hudson Bay is cyclonic. The 


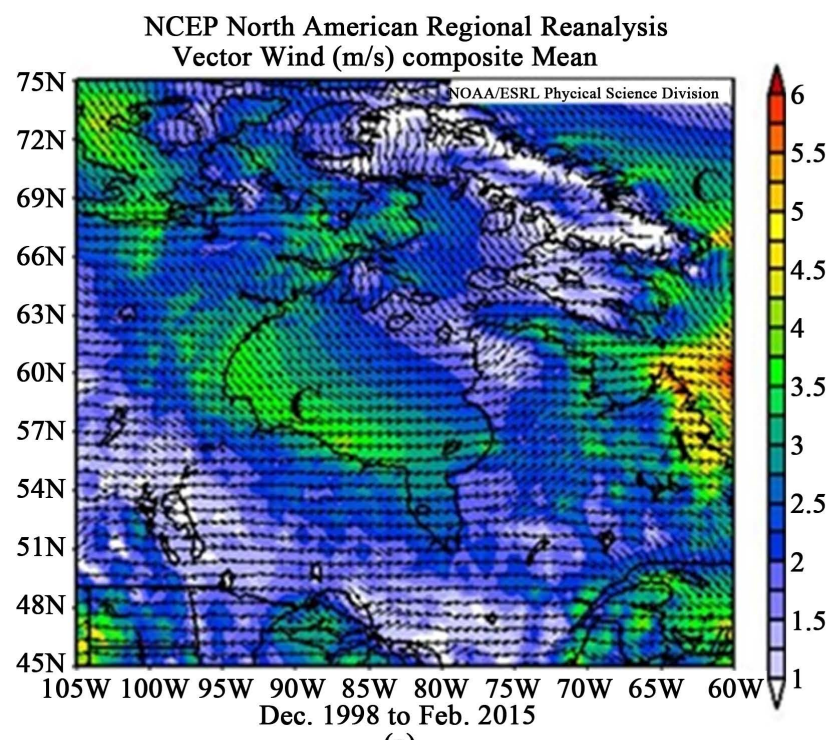

(a)

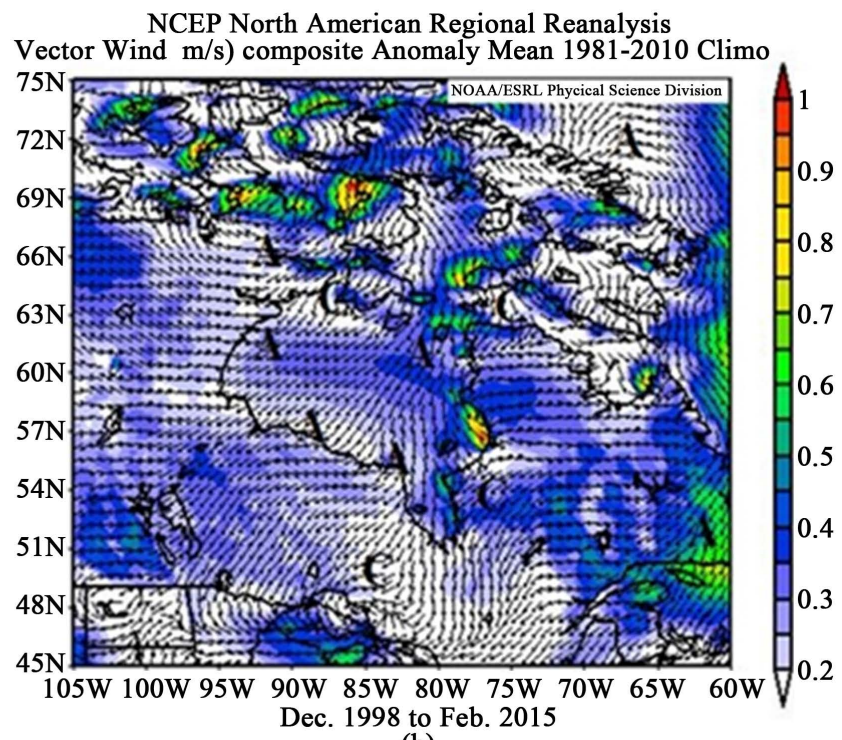

(b)

Figure 4. Mean wind vector at $1000 \mathrm{mb}$ during study period (a), wind vector anomaly map (b) for the same time departure from normal period.

anomaly map shows the increasing of the anti-cyclonic circulation over Hudson Bay during winter. In the east boundary and north west the contrast causing to increase the horizontal wind shear, between cyclonic and anti-cyclonic anomalies can be seen.

\subsection{Mean Sea Level Pressure (MSL)}

MSL pressure (Figure 5(a)) shows the existence of two cyclonic trough lines (red dash line) near the western and eastern boundaries of Hudson Bay and the anomaly map (Figure 5(b)) shows that the eastern trough has been deepened (pressure decreasing by $20 \mathrm{~Pa}$ in the north east to around $65 \mathrm{~Pa}$ in the east part of James Bay) whereas the western trough has been weakening (nearly $40 \mathrm{~Pa}$ increasing). The decreases (trough intensification with cyclonic circulation development) for the eastern trough are mostly over the areas with the increase in vertical motion of the Hudson Bay (see later in Section 5.6). This Figure also shows that horizontal pressure gradient (the change in pressure with distance which is proportional to acceleration in momentum equation) has been significantly increased (the area with the contrast between cyclonic and anti-cyclonic anomalies) over Hudson Bay eastern boundary and some parts in the north west. It is remarkable that $10 \mathrm{~m}$ wind analysis also shows the increase of the wind speed (due to momentum equation and the pressure gradient determining the wind velocity) mostly over eastern boundary and in north west area (see later in Section 5.3).

\subsection{Wind Speed Anomalies at $10 \mathrm{~m}$}

Figure 6 shows wind speed anomalies at $10 \mathrm{~m}$ during study period departure from normal period. The wind speed has been increased over the eastern 


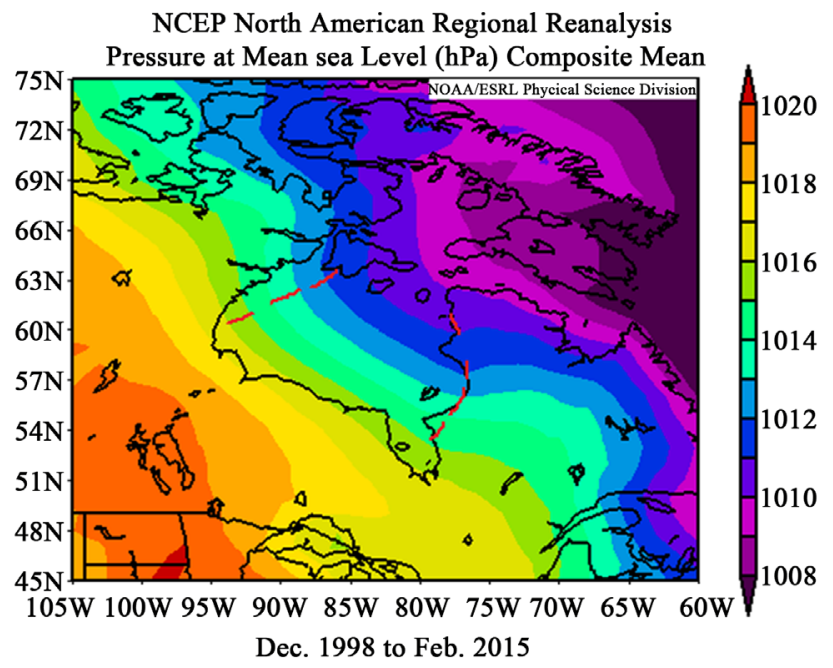

(a)
NCEP North American Regional Reanalysis

Pressure at Mean sea Level(Pa) Composite Anomaly 1981-2010 climo

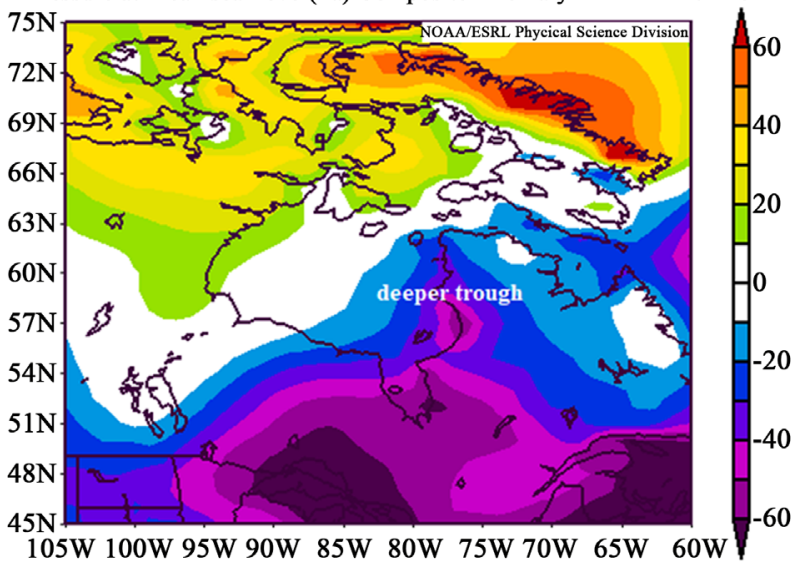

Dec. 1998 to Feb. 2015

(b)

Figure 5. Mean DJF sea level pressure (a) during study period, mean DJF sea level pressure anomalies (b) for the same time departure from normal period.

NCEP North American Regional Reanalysis

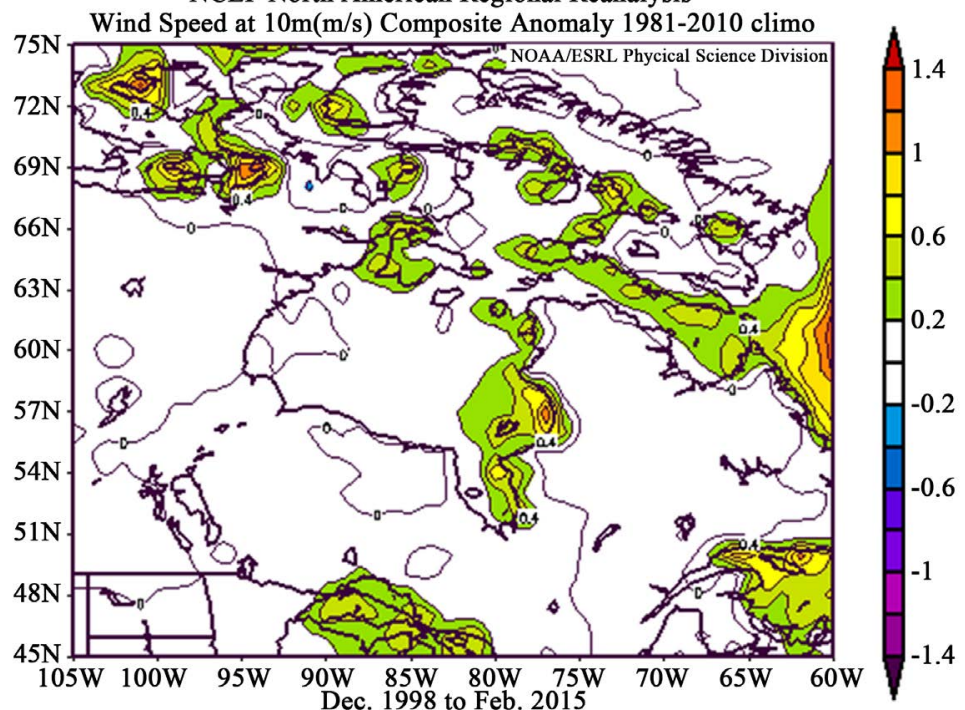

Figure 6. Wind speed anomalies at $10 \mathrm{~m}$ during study period departure from normal period.

boundary at around $0.2-1.4 \mathrm{~m} \cdot \mathrm{s}^{-1}$ and in north west area at around $0.2-0.8$ $\mathrm{m} \cdot \mathrm{s}^{-1}$. The maximum wind speed increase is around $1.4 \mathrm{~m} \cdot \mathrm{s}^{-1}$ in the eastern part in the Umiujaq area.

\subsection{Zonal and Meridional Winds Anomalies at $850 \mathrm{hPa}$}

Figure 7(a) shows the decreasing of zonal wind at level of $850 \mathrm{hPa}$ in all parts of Hudson Bay region from $0.2 \mathrm{~m} \cdot \mathrm{s}^{-1}$ in the north and east whereas the maximum values are in the north-central and southern boundary around $0.5 \mathrm{~m} \cdot \mathrm{s}^{-1}$. The zonal wind decreasing promises to decrease the westerly and rather colder currents. Figure 7(b) shows remarkable increase in the meridional wind mostly in 


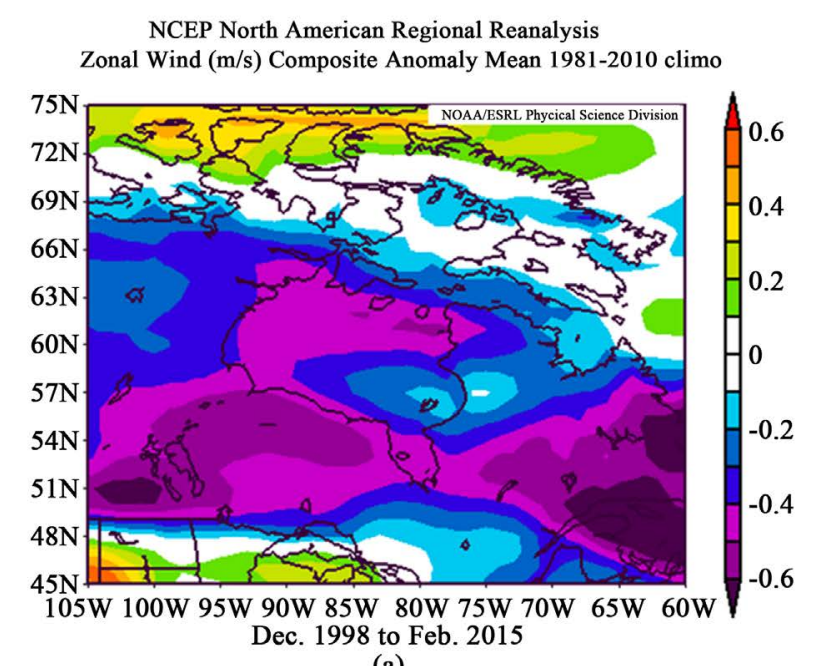

(a)

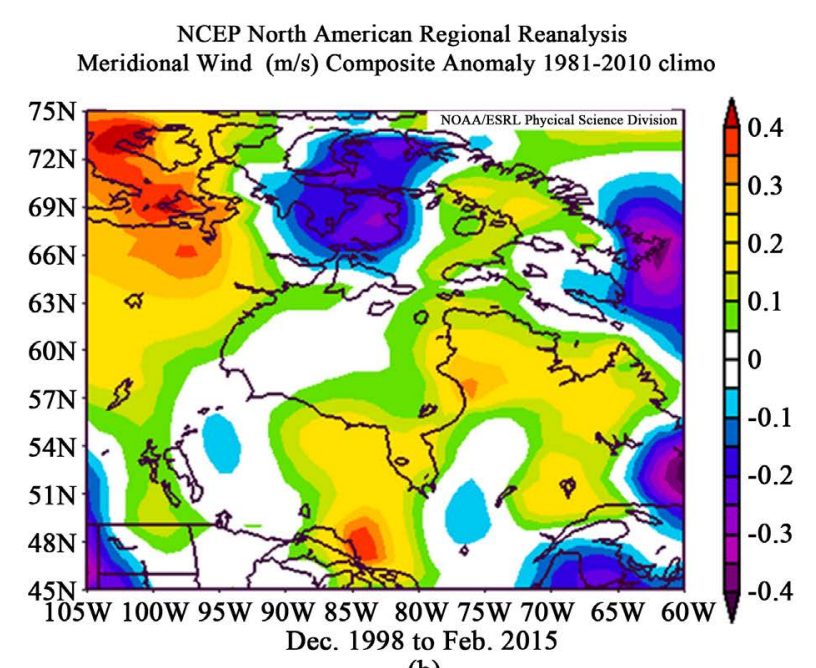

(b)

Figure 7. Zonal wind anomalies at level of $850 \mathrm{hPa}$ (a) during study period, meridional wind anomalies at level of $850 \mathrm{hPa}$; (b) for the same time with departure from normal period.

the eastern (at around $0.3 \mathrm{~m} \cdot \mathrm{s}^{-1}$ ), south (at around $0.1 \mathrm{~m} \cdot \mathrm{s}^{-1}$ ) and west (around $0.1 \mathrm{~m} \cdot \mathrm{s}^{-1}$ ) boundaries which shows the increase of rather warmer south-north currents in the east and south parts of Hudson Bay. The central part does not show any meridional anomaly.

\subsection{Vertical Profiles of Mean and Anomalies of Zonal Wind and Polar Jet Stream}

Figure 8(a) shows vertical profile of zonal wind in Hudson Bay area. The position of jet core in Hudson Bay region is around $250 \mathrm{mb}$. Figure 8 (b) shows the anomaly map for the same time which shows the weakening of the zonal polar jet at around $0.8 \mathrm{~m} \cdot \mathrm{s}^{-1}$ in the core mostly in $50^{\circ} \mathrm{N}-65^{\circ} \mathrm{N}$. Figure $8(\mathrm{c})$ shows mean North America map projection for the wind vector polar jet position at $200 \mathrm{hPa}$ during the study period. This Figure shows that the core of jet is below Hudson Bay with the maximum of $\sim 45 \mathrm{~m} \cdot \mathrm{s}^{-1}$. Figure $8(\mathrm{~d})$ shows the wind vector jet stream mean at same level and Figure 8(e) shows the anomaly map departure from normal period for the same time but in map projection over Hudson Bay region. Comparison of the last two later Figures shows that the wind direction has been changed from northwesterly (in mean map) to rather warmer south easterly flows during anomaly period. South easterly flows have been intensified in Hudson Bay with the maximum value $\sim 1.05 \mathrm{~m} \cdot \mathrm{s}^{-1}$ in core over south west of James Bay area during the anomaly period. Therefore, rather colder westerlies have been weakening during this anomaly time.

\subsection{Vertical Velocity at $700 \mathrm{hPa}$}

Figure 9(a) shows mean omega at $700 \mathrm{mb}$ during study period and Figure 9(b) shows omega anomaly map for the same time departure from normal period. The maximum increase in vertical motion is in the southern part of Hudson Bay in the James Bay at around $-0.015 \mathrm{~Pa} \cdot \mathrm{s}^{-1}$. The area with cyclonic circulation 


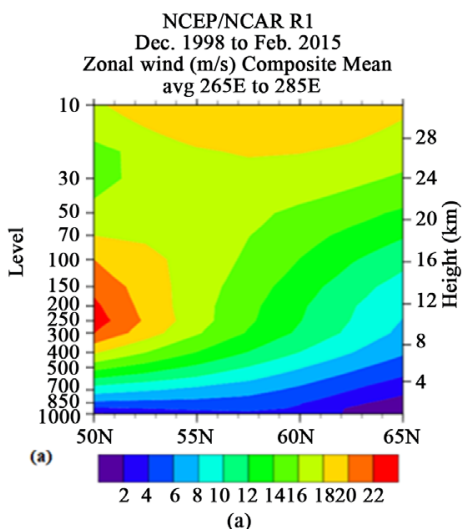

(a)

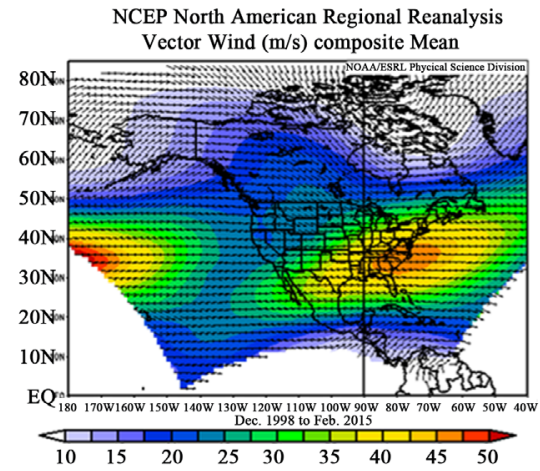

(c)

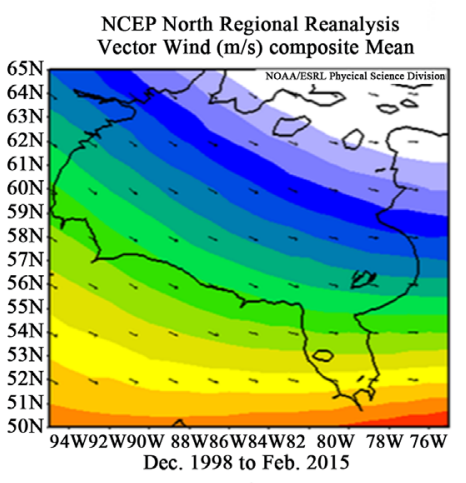

(d)

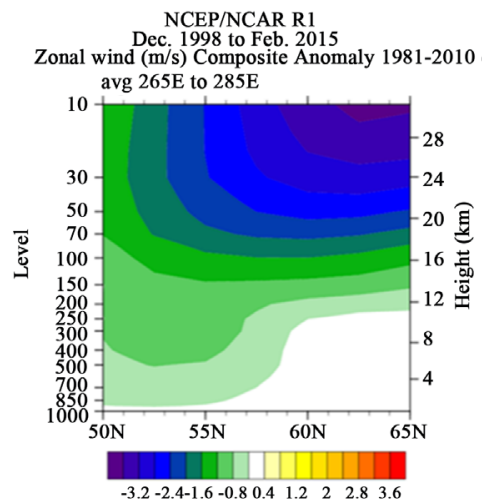

(b)

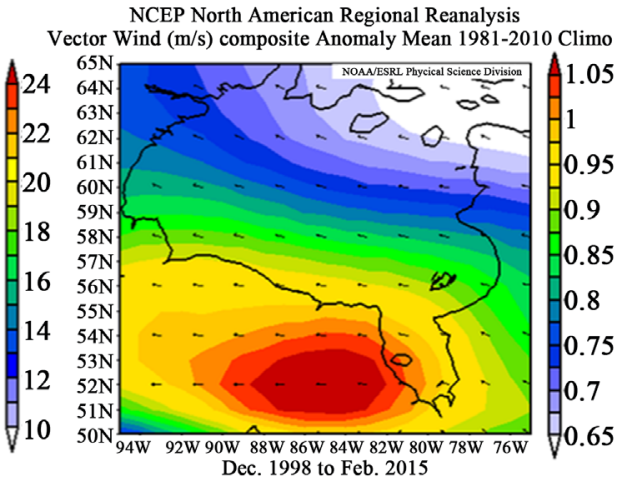

Figure 8. Mean vertical profile of zonal wind (a), vertical profile of zonal wind anomaly (b), mean North America wind vector polar jet position at $200 \mathrm{hPa}$ (c), mean wind vector jet stream in Hudson Bay at $200 \mathrm{hPa}$ (d) and the anomaly map for wind vector jet stream at $200 \mathrm{hPa}$ in Hudson Bay (e). All mean Figure s represent for study period and the anomaly maps represent for the same time departure from normal period. The colour bars show wind speed in $\mathrm{m} \cdot \mathrm{s}^{-1}$.

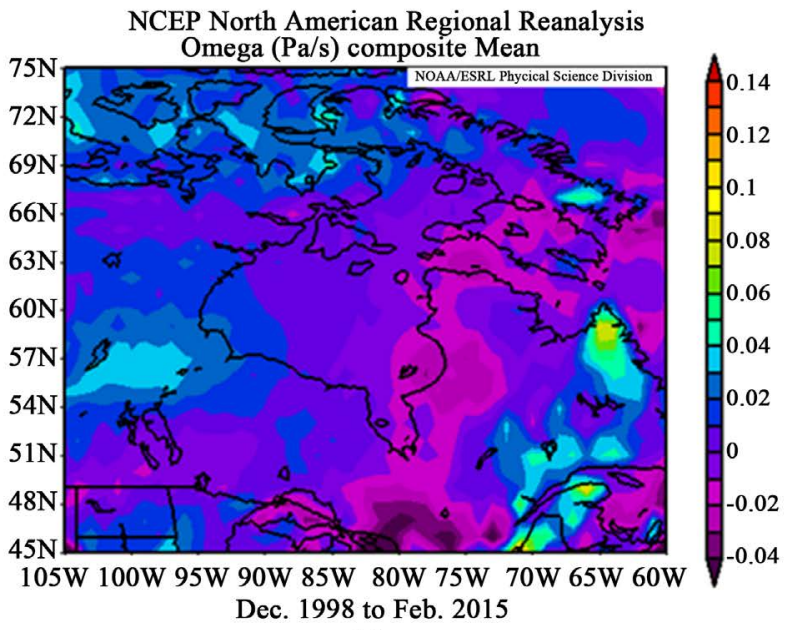

(a)

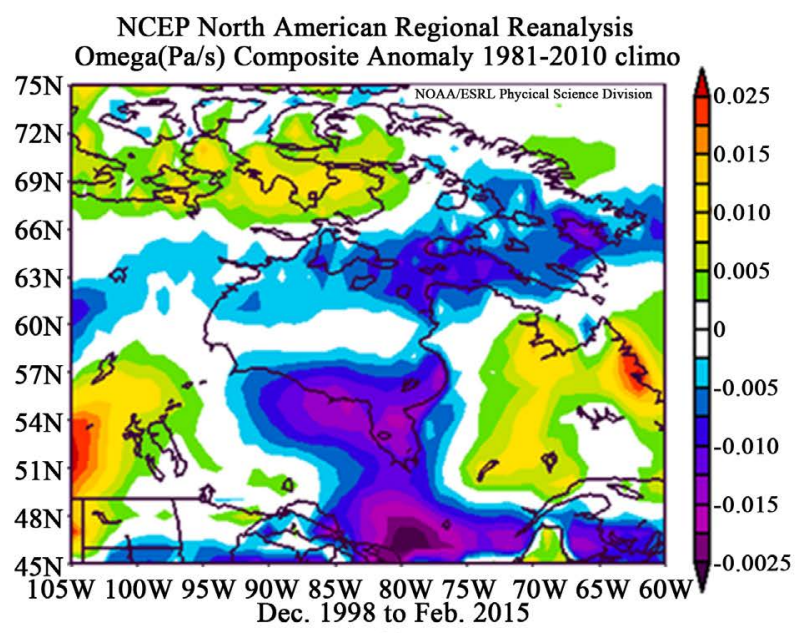

(b)

Figure 9. Mean omega at $700 \mathrm{hPa}$ (a) during study period, the omega anomaly map (b) for the same time with departure from normal period.

controls with negative omega anomalies and anti-cyclonic circulations are associated with positive anomalies of omega (vorticity map is not presented here). The recent climate change study [24] in Baffin Island as a part of the Canadian 
Arctic hasshown that the recent increase in $1000 \mathrm{mb}$ air temperature can be linked to vertical motion increasing (negative omega) and likely local increase in instability.

\subsection{2 m Air Temperature Anomaly Map}

Figure 10 shows the $2 \mathrm{~m}$ air temperature anomaly map. This Figure shows the increase of $2 \mathrm{~m}$ air temperature almost in the Hudson Bay region. The increase in $2 \mathrm{~m}$ air temperature in the boundary region in the north, east and south boundaries is remarkable with the maximum value at around $3.5 \mathrm{~K}$ in the east and around $5.5 \mathrm{~K}$ in the northwest area.

\subsection{Albedo at the Surface}

Figure 11(a) shows the albedo mean during December 1998-February 2015. Figure 11(b) shows the anomaly map for the same time departure from normal period. The mean albedo map shows the albedo values are changing from lower values around 35 percent in some narrow parts in the east to the maximum 75 percent in the north-west in Hudson Bay. Figure 11(b) shows that the albedo values have been decreased mostly in the north-west, eastern, some parts in the southern, east-central and also James Bay region around $5 \%$ along with $\sim 1 \mathrm{~K}$ increase in $2 \mathrm{~m}$ air temperature to the maximum value at around $15 \%-18 \%$ along with $\sim 4 \mathrm{~K}$ increase in $2 \mathrm{~m}$ air temperature.

\section{T-Test and Linear Regression Analysis during Winter Anomaly Period over Hudson Bay}

The t-tests for mean values of temperature at $2 \mathrm{~m}$, wind speed at $10 \mathrm{~m}$ and surface albedo during winter anomaly period (1998-2015) as the study period with

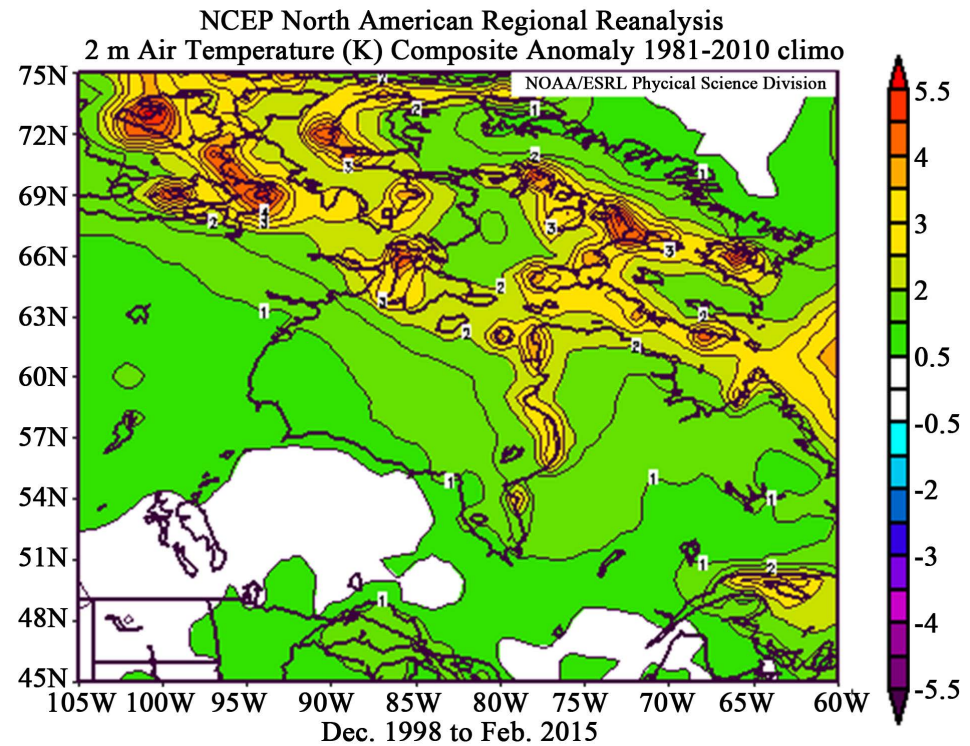

Figure 10. The map of the air temperature anomaly at $2 \mathrm{~m}$ during study period departure from normal period. 


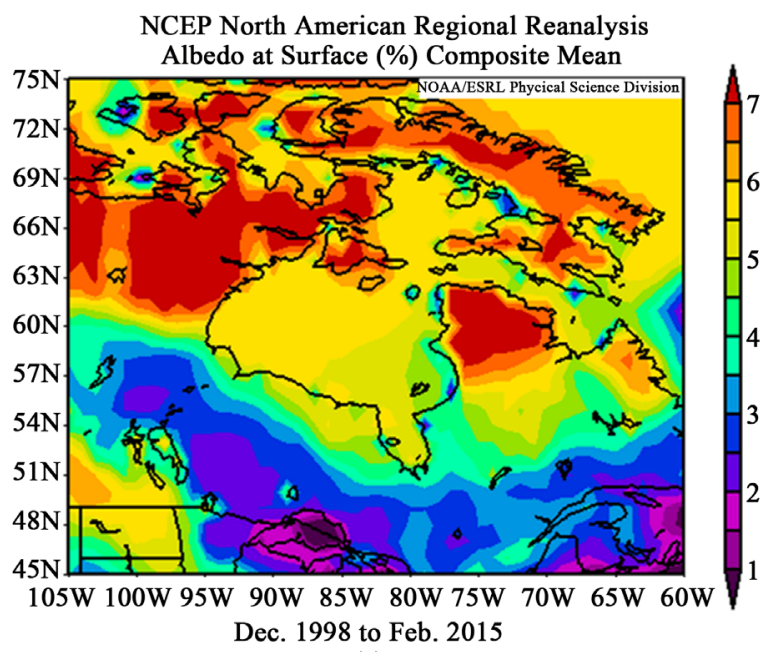

(a)

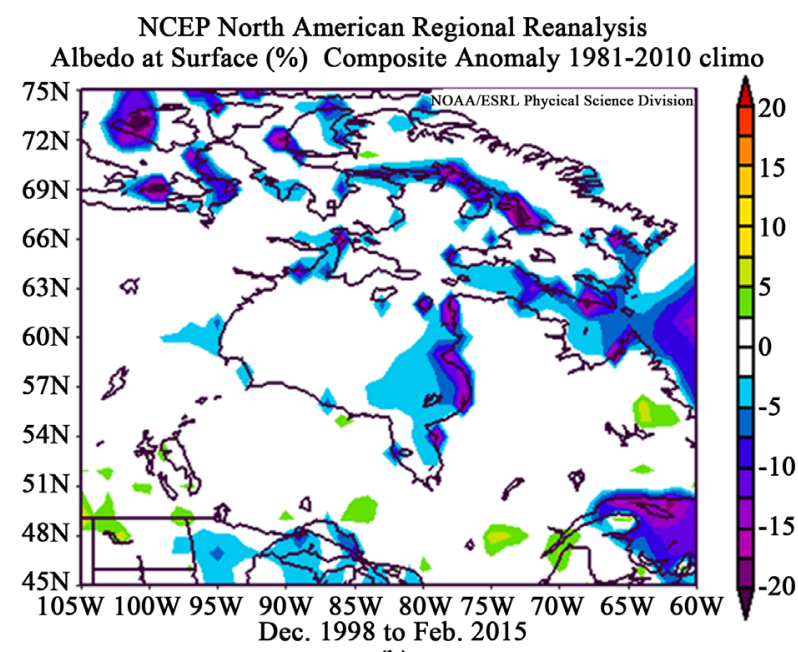

(b)

Figure 11. Mean albedo at the surface (a) during study period, albedo anomaly map (b) for the same time departure from normal period.

the normal period show a much smaller p-values rather than the significance level set at 0.05 . So consequently, $t$-test shows a significant difference during anomaly period (1998-2015) rather than the mean climatology (1981-2010) for mentioned parameters. The linear regression analysis of the winter temperature anomaly at $2 \mathrm{~m}$ against albedo anomaly shows the meaningful relationship between the decreased albedo and the increasing in temperature anomaly $\left(R^{2}=\right.$ $0.59, \mathrm{n}=699$, two-tail t-test at $\mathrm{p}$-value nearly zero) where the slope fits at $(-0.11$ * albedo anomaly +1.087$)$ in Kelvin degree * \% (Figure 12(a)). Also, the linear regression analysis of the winter wind speed anomaly at $10 \mathrm{~m}$ against air temperature anomaly at $2 \mathrm{~m}$ shows the meaningful relationship between the increased wind speed anomaly and the increasing in temperature anomaly $\left(\mathrm{R}^{2}=\right.$ $0.44, \mathrm{n}=699$, two-tail t-test at $\mathrm{p}$-value nearly zero) and the slope fits at $(0.22$ * temperature anomaly -0.17 ) in $\mathrm{ms}^{-1} \mathrm{~K} * \%$ (Figure 12(b)). Figure 12(c) shows the linear regression analysis of the anomaly winter accumulation total evaporation at surface against albedo anomaly which has the meaningful relationship between the decreased albedo and the increasing in winter accumulation total evaporation at surface $\left(\mathrm{R}^{2}=0.97, \mathrm{n}=699\right.$, two-tail t-test at $\mathrm{p}$-value nearly zero) and the slope fits at $\left(-0.0062 *\right.$ albedo anomaly $\left.-6 * 10^{-5}\right) \mathrm{in} \mathrm{kg} \cdot \mathrm{m}^{-2} * \%$. This shows the increased ice melt is increasing evaporation in a statistically significant way.

\section{Summary and Conclusions}

The physical and meteorological high-resolution data set from NARR (The North American Regional Reanalysis Model) and NCEP (National Center for Atmospheric Research) have been investigated to understand the recent wind changes along with the possible relation to other physical and meteorological factors such as surface albedo, sea ice decline, temperature and evaporation in Hudson Bay. Here, at the first step, the long-term daily maximum and minimum 


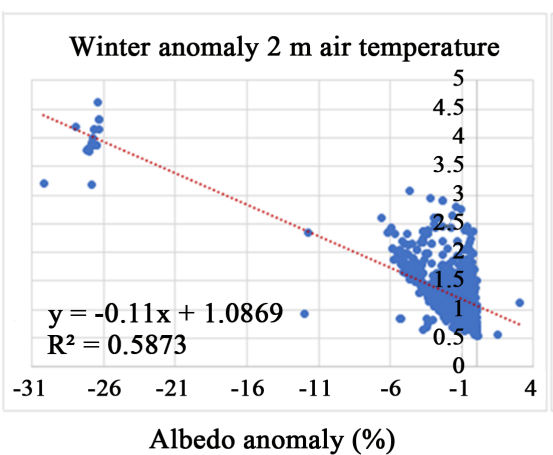

(a)

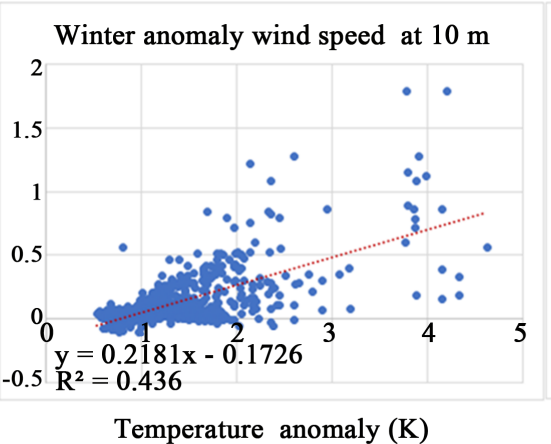

(b)

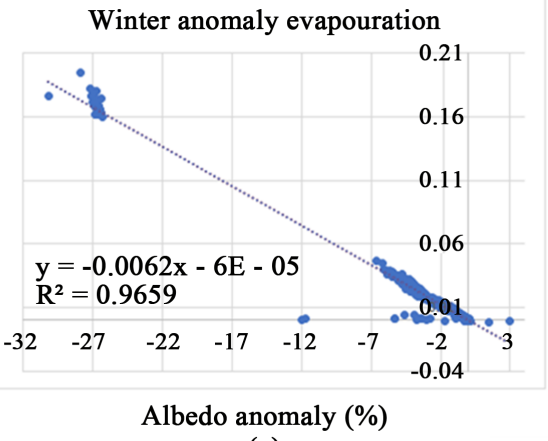

(c)

Figure 12. Anomaly air temperature at $2 \mathrm{~m}$ against anomaly albedo (a), anomaly wind speed at $10 \mathrm{~m}$ against anomaly air temperature at $2 \mathrm{~m}$ (b) and anomaly accumulated total evaporation at the surface against albedo anomaly (c). All Figure s represent for study period departure from normal period.

Hovmöller diagrams (figures have been not presented here) and yearly mean surface temperatures and yearly mean sea surface temperature analysis from 1948 to 2015 have been analysed. These results clearly have denoted a rapid warmer time for the Hudson Bay area from late 1998. For the next step, parameters such as surface albedo, $1000 \mathrm{mb}$ wind vectors, MSL pressure, zonal and meridional winds at $850 \mathrm{hPa}$, polar jet, vertical velocity at $700 \mathrm{hPa}$ and $2 \mathrm{~m}$ air temperature, during wintertime from 1998 to 2015, for mean values and anomalies with departure from normal period have been examined. The results indicate that during the anomaly period, the near-surface air temperatures at $2 \mathrm{~m}$ have been increased in most parts of Hudson Bay with remarkable increases in the boundary regions in the north, east and south with the maximum values at around $4 \mathrm{~K}$ in the east and at around $6 \mathrm{~K}$ in the north-west area. Seasonal winter time analysis of the $10 \mathrm{~m}$ wind speed anomaly has shown the increases of wind speed mostly over south of Hudson Bay in James Bay area, east and north-west boundaries of Hudson Bay with the greatest values over the eastern part at around $1.4 \mathrm{~m} \cdot \mathrm{s}^{-1}$ in maximum value. The wind speed has been increased over the north-west area at around $0.2-0.8 \mathrm{~m} \cdot \mathrm{s}^{-1}$. The wind vector at $1000 \mathrm{mb}$ analysis has been revealed anti-cyclonic anomaly pattern over the most parts of Hudson Bay. Recent studies of the atmospheric circulation anomalies and trends during winter have shown, a link between accelerating of the summer sea ice decreases over the eastern areas of Europe and north of Alaska associated with the recent strong anti-cyclonic circulation [11]. Also, the study of the composite mean surface wind stress and sea ice anomaly vectors during summer with the composites of ice-loss and ice-gain years have revealed the contribution of the yearly September sea ice area changes to the anti-cyclonic circulation over the Arctic during the ice-loss years whereas the cyclonic circulation is linked to the ice-gain years [12]. Also, wind vector anomalies at $1000 \mathrm{mb}$, have shown the contrast pattern between cyclonic and anti-cyclonic local wind circulations over Hudson Bay area mostly over east, north and north-west. This can be associated with the change in mean sea level pressure patterns and pressure gradient increase. The 
study results indicate that over the areas with the contrast structure between cyclonic and anti-cyclonic circulation would result in increasing the horizontal wind shear leads to speedup the near-surface wind. Likewise, the wind vector analysing at different pressure levels shows the change in wind direction mostly from northwesterly (zonal wind weakening) to south and easterlies. The weakening of the zonal winds can be linked to the reduction of the pole to mid-latitude temperature gradient causing the enhanced Arctic warming [25] [26]. The zonal wind speed at $850 \mathrm{hpa}$ along with its vertical structure has been weakened versus the meridional wind intensification at $850 \mathrm{mb}$ mostly over the south and east during winter.

Upper atmospheric transport including jet stream like the polar jet wind vectors at $200 \mathrm{mb}$ during anomaly time has revealed the changes in magnitude and position. During winter anomaly time the polar jet at $200 \mathrm{mb}$ has been shifted mostly from rather mean colder northwesterly flows to the rather warmer south and easterly anomaly flows over Hudson Bay areas. These results agree with the recent studies related to rapid Arctic warming linked to more common high-amplitude (wavy) jet stream and smaller westerlies structure of weaker zonal upper-level winds, and a more meridional flow direction [27].

Surface albedo has also been decreased mostly in the north-west, eastern, some part in the southern, east-central part and James Bay region around 5\% $(\sim 1 \mathrm{~K}$ increase in $2 \mathrm{~m}$ air temperature) to maximum value at around $15 \%-18 \%$ $(\sim 4 \mathrm{~K}$ increase in $2 \mathrm{~m}$ air temperature) during winter anomaly period.

Additionally, the yearly historical ice coverage from 1980 to 2015 for north, north-west, east and central parts of Hudson Bay has shown a negative yearly trend for all parts of Hudson Bay changing from largest to lowest values in the north $(\sim-3.25(+/-1.86) \%$ per decade $)$, north-west $(\sim-2.36(+/-1.2) \%$ per decade), east $(\sim-1.99(+/-1.56) \%$ per decade $)$ and central part $(\sim-1.57(+/-1.24) \%$ per decade) respectively.

The statistical analysis such as t-tests for the temperature at $2 \mathrm{~m}$, wind speed at $10 \mathrm{~m}$ and surface albedo for mean values during winter anomaly period (1998-2015) with mean climatology values (1981-2010) has shown an existence of a significant difference between anomaly period and climatology periodic time for mentioned parameters over Hudson Bay. The linear regression analysis of the anomaly winter temperature at $2 \mathrm{~m}$ against albedo anomaly and between the anomaly wind speed at $10 \mathrm{~m}$ against anomaly $2 \mathrm{~m}$ air temperature represents a meaningful relationship between these variables. Also, a linear regression analysis of the anomaly accumulation of total evaporation at surface against albedo anomaly shows a meaningful relationship between the decreased albedo and the increasing in winter accumulation total evaporation at the surface. This shows the increased ice melt can increase the evaporation in a meaningful statistical way. This study has shown many changes in winter atmospheric and surface conditions significantly in the north, north-west and eastern boundaries which have been quite dramatic over the anomaly period over Hudson Bay. 


\section{Acknowledgements}

Thanks are given to NOAA/ESRL PSD, Physical Science Division, Boulder Colorado web page through http://www.esrl.noaa.gov/psd/, Canadian ice service webpage through http://iceweb1.cis.ec.gc.ca/IceGraph/page1.xhtml and Canadian census website through

http://www12.statcan.gc.ca/census-recensement/2011/geo/bound-limit/bound-li mit-2011-eng.cfm. I would like to thank Prof. Bello and Prof. Higuchi for suggestion and comments. Great thanks to Prof. Peter Taylor for useful comments and editing the text.

\section{Conflicts of Interest}

The author declares no conflicts of interest regarding the publication of this paper.

\section{References}

[1] Hansen, J., Sato, M., Ruedy, R., Lo, K., Lea, D.W. and Medina-Elizade, M. (2006) Global Temperature Change. Proceedings of the National Academy of Sciences of the United States of America, 103, 14288-14293. https://doi.org/10.1073/pnas.0606291103

[2] Blunden, J. and Arndt, D.S. (2012) State of the Climate in 2011. Bulletin of the American Meteorological Society, 93, S1-S264. https://doi.org/10.1175/2012BAMSStateoftheClimate.1

[3] Döscher, R., Vihma, T. and Maksimovich, E. (2014) Recent Advances in Understanding the Arctic Climate System State and Change from a Sea Ice Perspective: A Review. Atmospheric Chemistry and Physics Discussions, 14, 10929-10999. https://doi.org/10.5194/acpd-14-10929-2014

[4] Polyakov, I.V., Alexeev, V.A., Belchansky, G.I., Dmitrenko, I.A., Ivanov, V.V., Kirillov, S.A., Yashayaev, I., et al. (2008) Arctic Ocean Freshwater Changes over the Past 100 Years and Their Causes. Journal of Climate, 21, 364-384. https://doi.org/10.1175/2007JCLI1748.1

[5] Polyakov, I.V., Alexeev, V.A., Ashik, I.M., Bacon, S., Beszczynska-Möller, A., Carmack, E.C., Woodgate, R., et al. (2011) Fate of Early 2000s Arctic Warm Water Pulse. Bulletin of the American Meteorological Society, 92, 561-566.

https://doi.org/10.1175/2010BAMS2921.1

[6] Bourgain, P. and Gascard, J.C. (2012) The Atlantic and Summer Pacific Waters Variability in the Arctic Ocean from 1997 to 2008. Geophysical Research Letters, 39. https://doi.org/10.1029/2012GL051045

[7] Pirazzoli, P.A., Regnauld, H. and Lemasson, L. (2004) Changes in Storminess and Surges in Western France during the Last Century. Marine Geology, 210, S307-S323. https://doi.org/10.1016/j.margeo.2004.05.015

[8] Pirazzoli, P. and Tomasin, A. (2003) Recent Near-Surface Wind Changes in the Central Mediterranean and Adriatic Areas. International Journal of Climatology, 23, 963-973. https://doi.org/10.1002/joc.925

[9] Pirazzoli, P.A. and Tomasin, A. (1999) Recent Abatement of Easterly Winds in the northern Adriatic. International Journal of Climatology, 19, 1205-1219. https://doi.org/10.1002/(SICI)1097-0088(199909)19:11<1205::AID-JOC405>3.3.CO; 
$\underline{2-4}$

[10] Garreaud, R.D. and Falvey, M. (2009) The Coastal Winds off Western Subtropical South America in Future Climate Scenarios. International Journal of Climatology, 29, 543-554. https://doi.org/10.1002/joc.1716

[11] Ogi, M. and Rigor, I.G. (2013) Trends in Arctic Sea Ice and the Role of Atmospheric Circulation. Atmospheric Science Letters, 14, 97-101. https://doi.org/10.1002/asl2.423

[12] Screen, J.A., Simmonds, I. and Keay, K. (2011) Dramatic Interannual Changes of perennial Arctic Sea Ice Linked to Abnormal Summer Storm Activity. Journal of Geophysical Research, 116. https://doi.org/10.1029/2011JD015847

[13] Maxwell, J.B. (1986) A Climate Overview of the Canadian Inland Seas. In: Martini, I.P., Ed., Canadian Inland Seas, Elsevier, Amsterdam, 79-99. https://doi.org/10.1016/S0422-9894(08)70898-5

[14] Rouse, W.R. (1991) Impacts of Hudson Bay on the Terrestrial Climate of the Hudson Bay Lowlands. Arctic and Alpine Research, 23, 24.

https://doi.org/10.2307/1551433

[15] Gough, W. and Leung, A. (2002) Nature and Fate of Hudson Bay Permafrost. Regional Environmental Change, 2, 177-184. https://doi.org/10.1007/s10113-002-0048-x

[16] Markham, W. (1986) The Ice Cover. In: Martini, I.P., Ed., Canadian Inland Seas (Elsevier Oceanography Series), Elsevier, New York, 101-116. https://doi.org/10.1016/S0422-9894(08)70899-7

[17] Saucier, F.J. and Dionne, J. (1998) A 3-D Coupled Ice-Ocean Model Applied to Hudson Bay, Canada: The Seasonal Cycle and Time-Dependent Climate Response to Atmospheric Forcing and Runoff. Journal of Geophysical Research, 103, Article ID: 27689. https://doi.org/10.1029/98JC02066

[18] Wang, J., Mysak, L.A. and Ingram, R.G. (1994) Interannual Variability of Sea-Ice Cover in Hudson Bay, Baffin Bay and the Labrador Sea. Atmosphere-Ocean, 32, 421-447. https://doi.org/10.1080/07055900.1994.9649505

[19] Mysak, L., Ingram, R., Wang, J. and Van der Baaren, A. (1996) The Anomalous Sea-Ice Extent in Hudson Bay, Baffin Bay and the Labrador Sea during Three Simultaneous NAO and ENSO Episodes. Atmosphere-Ocean, 34, 313-343. https://doi.org/10.1080/07055900.1996.9649567

[20] Gough, W.A., Cornwell, A.R. and Tsuji, L. (2004) Trends in Seasonal Sea Ice Duration in Southwestern Hudson Bay. Arctic, 57, 299-305. https://doi.org/10.14430/arctic507

[21] Etkin, D.A. (1991) Break-up in Hudson Bay: Its Sensitivity to Air Temperatures and Implications for Climate Warming. Climatological Bulletin, 25, 21-34.

[22] Mesinger, F., DiMego, G., Kalnay, E., Mitchell, K., Shafran, P.C., Ebisuzaki, W., Shi, W., et al. (2006) North American Regional Reanalysis. Bulletin of the American Meteorological Society, 87, 343-360. https://doi.org/10.1175/BAMS-87-3-343

[23] Kalnay, E., Kanamitsu, M., Kistler, R., Collins, W., Deaven, D., Gandin, L., Joseph, D., et al. (1996) The NCEP/NCAR 40-Year Reanalysis Project. Bulletin of the American Meteorological Society, 77, 437-471. https://doi.org/10.1175/1520-0477(1996)077<0437:TNYRP >2.0.CO;2

[24] Fazel-Rastgar, F. (In Press) The Evidence of Recent Canadian Arctic Climate Change: A Case Study, the Baffin Island. International Journal of Global Warming.

[25] Cohen, J., Screen, J.A., Furtado, J.C., Barlow, M., Whittleston, D., Coumou, D., 
Jones, J., et al. (2014) Recent Arctic Amplification and Extreme Mid-Latitude Weather. Nature Geoscience, 7, 627-637. https://doi.org/10.1038/ngeo2234

[26] Walsh, J.E. (2014) Intensified Warming of the Arctic: Causes and Impacts on Middle Latitudes. Global and Planetary Change, 117, 52-63.

https://doi.org/10.1016/j.gloplacha.2014.03.003

[27] Francis, J.A. and Vavrus, S.J. (2015) Evidence for a Wavier Jet Stream in Response to Rapid Arctic Warming. Environmental Research Letters, 10, Article ID: 014005. https://doi.org/10.1088/1748-9326/10/1/014005 